Jurdimas (Jurnal Pengabdian Kepada Masyarakat) Royal

Vol. 4 No. 2, Mei 2021, hlm. 157 - 164

ISSN 2614-7912 (Print)

DOI: https://doi.org/10.33330/jurdimas.v4i2.974

ISSN 2622-3813 (Online)

Available online at https://jurnal.stmikroyal.ac.id/index.php/jurdimas

\title{
MENINGKATKAN KEMAMPUAN SPEAKING DAN WRITING BAHASA INGGRIS MELALUI KOMPETISI SPELLING BEE
}

\author{
Shally Amna ${ }^{1}$, Wienda Gusta ${ }^{1}$, Yeng Primawati ${ }^{1}$ \\ ${ }^{1}$ Program Studi Sistem Informasi, Universitas Putra Indonesia YPTK Padang \\ e-mail: *shallyamna@gmail.com
}

\begin{abstract}
Spelling Bee is a word spelling game which assessed the accuracy of words and the pronunciation of the letters in English. MTSN 7 Bungus, Padang was chosen as PKM partners due to the students' low English language skills and interest. Therefore, through the Spelling Bee competition, the team tried to improve the students' skills and interest in learning English language, especially their ability to write and spell words correctly. In this competition, there were 280 students previously trained before join the competition. This competition is divided into three rounds, namely the preliminary round, the semi-final round and the final round. In addition, the English teachers also helped to coordinate the competition. During the activity, students were also given lessons on writing and spelling correctly. As a result, students' enthusiasm in participating in competition can be one of the factors that triggers the enthusiasm and interests in learning so that they get more satisfying learning outcomes. During the competition, students were guided by the English teachers and given clear instructions. After participating in Spelling Bee competition, the students were not only given rewards but also some improvement in their English writing and spelling skills.
\end{abstract}

Key Words: Spelling Bee, writing, spelling.

\begin{abstract}
Abstrak : Spelling Bee merupakan permainan mengeja kata dengan menilai keakuratan kata dan ketepatan pengucapan huruf yang disebutkan dalam Bahasa Inggris. MTSN 7 Bungus, Padang dipilih sebagai mitra PKM karena kemampuan dan minat Bahasa Inggris siswanya yang sangat rendah. Oleh karena itu, lewat kompetisi Spelling Bee, Tim PKM berusaha untuk meningkatkan kemampuan dan minat siswa terhadap Bahasa Inggris terutama pada kemampuan menulis dan mengeja kata. Dalam Kegiatan Spelling Bee ini, sebanyak 280 siswa dilatih sebelum mengikuti kompetisi Spelling Bee yang terbagi atas tiga babak, yaitu preliminary Round, Semi Final Round dan yang terakhir Final round. Selain itu, guru Bahasa Inggris di sekolah tersebut turut membantu demi kelancaran kegiatan kompetisi ini. Siswa diberikan pelajaran tentang menulis dan mengeja bahasa Inggris dengan benar. Antusias siswa dalam mengikuti kompetisi dapat merupakan salah satu faktor yang memicu semangat dan daya tarik siswa dalam belajar sehingga memperoleh hasil belajar yang jauh lebih memuaskan. Selama kompetisi, siswa dipandu oleh guru bahasa Inggrisnya dan diberikan instruksi yang jelas. Setelah mengikuti kompetisi Spelling Bee ini, siswa siswi MTSN 7 Bungus tidak hanya diberikan reward namun juga dapat meningkatkan kemampuan menulis dan mengeja Bahasa Inggrisnya.
\end{abstract}

Kata Kunci: spelling bee; writing; spelling. 
Jurdimas (Jurnal Pengabdian Kepada Masyarakat) Royal

Vol. 4 No. 2, Mei 2021, hlm. 157 - 164

ISSN 2614-7912 (Print)

DOI: https://doi.org/10.33330/jurdimas.v4i2.974

ISSN 2622-3813 (Online)

Available online at https://jurnal.stmikroyal.ac.id/index.php/jurdimas

\section{PENDAHULUAN}

Pelajaran Bahasa Inggris sudah mulai diajarkan secara wajib pada tingkat SMP se-Indonesia. Dalam kurikulumnya, pelajaran Bahasa Inggris yang diberikan di tingkat ini sudah memasuki tingkat English proficiency dimana siswa tidak lagi belajar mulai dari mengeja dan mengenal kata dalam Bahasa Inggris, namun sudah mulai menggunakannya dalam bentuk konteks iklan, pengumuman, bacaan hingga tenses. Dengan tingginya tuntutan kurikulum ini, banyak siswa setingkat SMP yang kesulitan untuk mengikuti materi pelajaran dan mendapatkan nilai yang memuaskan.

Untuk dapat menguasai semua kompetensi Bahasa Inggris yang ditargetkan pada tingkat SMP, siswa harus menguasai semua skill yaitu Speaking, Listening, Writing, and Grammar. Speaking skill atau kemampuan berbicara dalam Bahasa Inggris memerlukan pengetahuan tentang cara pengucapan (pronunciation) mulai dari huruf, kata hingga kalimat. Banyak para ahli yang telah menyatakan bahwa Bahasa Inggris memiliki sistem pengejaan yang rumit (Yule, 2006) and (Waller, 2002). Berbeda jauh dengan Bahasa Indonesia, pengucapan dan penulisan huruf dan kata dalam Bahasa Inggris tidak selalu sama bahkan banyak yang jauh berbeda antara apa yang tertulis dengan apa yang harus dibaca. Kombinasi antara huruf vokal dan huruf konsonan juga menghasilkan pronounciation yang berbeda. Kata flower dan flour memiliki komposisi huruf yang berbeda, arti kata yang berbeda, namun pengucapannya sama. Selain itu, kata read di present dan Read di past verb memiliki arti dan komposisi huruf yang sama namun pengucapannya berbeda. hal yang paling sulit dalam penulisan ejaan Bahasa Inggris adalah huruf vokalnya (Rollings, 2004). Kata food dan blood memiliki komposisi huruf vokal yang sama namun pronounciation yang jauh berbeda yaitu [fuwd] dan [blad].

Spelling atau ejaan memiliki fungsi yang sangat besar dalam menulis, kesan pertama yang didapati oleh pembaca adalah ejaan kata dari sebuah tulisan sebelum dia memahami pesan yang ingin disampaikan oleh penulis (Phoenix \& Scott-Dunne, 1994). Sebuah tulisan dengan variasi kata yang banyak lebih menarik untuk dibaca daripada sebuah tulisan yang menggunakan kata yang sama berulang-ulang kali. Banyak siswa merasa bahwa menulis dengan ejaan yang benar sangat sulit sekali untuk dilakukan (Strickland, 2011). Sering kali yang terjadi adalah, ketika siswa diminta untuk menulis, mereka cenderung memilih menggunakan kata yang sama berulang-ulang kali karena kurangnya kosa kata yang dimiliki dan tidak mengetahui ejaan kata yang harus digunakan. Selain itu, (Kamhi \& Hilton, 2000) dalam penelitiannya menemukan bahwa siswa yang memiliki kemampuan mengeja yang buruk memiliki gaya belajar bahasa Inggris yang berbeda dengan siswa yang memiliki kemampuan mengeja yang baik. Siswa dengan kemampuan mengeja yang buruk mengandalkan strategi visual dengan mengingat bentuk kata dan bukannya mengingat bagaimana bunyi dan susunan dari huruf-huruf yang membentuk kata tersebut. Dengan menggunakan strategi tersebut, siswa dengan kemampuan mengeja yang buruk memiliki kemampuan menulis dan mengucapkan bahasa Inggris yang jauh lebih rendah dari pada siswa yang mampu mengeja dengan baik. 
Jurdimas (Jurnal Pengabdian Kepada Masyarakat) Royal

Vol. 4 No. 2, Mei 2021, hlm. 157 - 164

ISSN 2614-7912 (Print)

DOI: https://doi.org/10.33330/jurdimas.v4i2.974

ISSN 2622-3813 (Online)

Available online at https://jurnal.stmikroyal.ac.id/index.php/jurdimas

Spelling Bee adalah kompetisi mengeja dalam Bahasa Inggris. Dalam kompetisi ini, siswa akan diminta untuk mengeja huruf demi huruf, menuliskan kata dan mengucapkannya dengan benar. Dari semua aktifitas yang ada dalam kompetisi ini, banyak manfaat yang bisa diperoleh diantaranya adalah meningkat-nya kemampuan spelling, speaking dan writing Bahasa Inggrisnya. Dengan mengetahui bagaimana ejaan sebuah kata dengan benar , siswa dapat menuliskan dan mengucapkan kata tersebut dengan benar. Disamping itu, Spelling Bee juga merupakan salah satu cara yang menyenangkan dalam belajar dan berkompetisi untuk menumbuhkan minat dan kemampuan siswa dalam Bahasa Inggris.

Spelling Bee merupakan salah satu game yang paling banyak dicobakan di kelas untuk meningkatkan kemampuan Bahasa Inggris siswa. Hal ini sudah dibuktikan di banyak penelitian terdahulu, diantaranya adalah (Yusuf, Mustafa, \& Muzdhalifah, 2017) telah menerapkan Spelling Bee untuk meningkatkan kemampuan siswa kelas VII di SMP di Banda Aceh. Berdasarkan hasil penelitian ini, mereka juga menyarankan agar Spelling Bee dapat digunakan sebagai salah satu strategi pembelajaran Bahasa Inggris. Kemudian (Aprillia, 2018) dalam penelitiannya telah menemukan peningkatan penggunaan kosakata siswa di SMP Muhammadiyah Ahmad Dahlan Metro setelah melakukan permainan Spelling Bee. Berikutnya, (Syakira, 2018) dalam penelitiannya menemukan adanya pengaruh signifikan penggunaan permainan Spelling Bee untuk meningkatkan pemahaman membaca siswa di SMP negeri 40 Pekanbaru, Riau.
Sebelum mengadakan kompetisi Spelling Bee ada beberapa kegiatan yang perlu dilaksanakan diantaranya seperti memberi tahu guru Bahasa Inggris siswa untuk me-review pelajaran Spelling dan Writing, menyeleksi buku bacaan Bahasa Inggris siswa untuk mencari kata-kata yang akan gunakan dalam kompetisi, dan mengatur tingkat kesulitan soal dengan tingkat kompetensi siswa.

Pada kegiatan PKM ini, tim dosen PKM dari UPI YPTK telah mensurvey sejumlah lokasi untuk mengadakan kompetisi Spelling Bee. Adapun lokasi pelaksanaan PKM Spelling Bee ini yaitu di Madrasah Tsanawiyah MTSN 7 Bungus, Padang. Jalan Kayu Aro Bungus Barat, Teluk Kabung, Kota Padang, Sumatera Barat. Berdasarkan hasil pengamatan, MTSN 7 Bungus adalah salah satu sekolah Tingkat pertama Negeri Tsnaawiyah yang jumlah kosakata anak didiknya masih tergolong sedikit khususnya di kelas 8 . Selain itu, banyak siswa yang masih membutuhkan support dan dorongan untuk dapat lebih percaya diri dalam berbahasa Inggris serta rendahnya kemampuan dalam berbicara dan menulis Bahasa Inggris. Oleh karena itu, tim PKM melihat bahasa Kompetisi Spelling Bee dapat dijadikan solusi dalam mengatasi permasalahan yang ada.

Secara garis besarnya, permasalahan mitra adalah (1) Memiliki keterbatasan kosakata baik dalam membaca maupun menulis dalam bahasa Inggris, (2) Kurangnya rasa percaya diri dan motivasi dalam belajar bahasa Inggris dan Memiliki kemampuan yang masih rendah dalam berbicara dan menulis dalam bahasa Inggris.

Tujuan dari PKM Spelling Bee ini
adalah sebagai berikut, (1) Mampu 
Jurdimas (Jurnal Pengabdian Kepada Masyarakat) Royal

Vol. 4 No. 2, Mei 2021, hlm. 157 - 164

ISSN 2614-7912 (Print)

DOI: https://doi.org/10.33330/jurdimas.v4i2.974

ISSN 2622-3813 (Online)

Available online at https://jurnal.stmikroyal.ac.id/index.php/jurdimas

mengeja dan mengenali kosakata Bahasa Inggris dengan benar, (2) Menambah jumlah pengetahuan kosa kata siswa dalam Bahasa Inggris, (3) Memberikan semangat dan motivasi bagi siswa dalam belajar Bahasa Inggris, (4) Memiliki rasa percaya diri dalam berbahasa Inggris dan Meningkatkan kemampuan berbicara dan menulis dalam Bahasa Inggris.

\section{METODE}

Dalam kegiatan pengabdian kepada masyarakat ini cara yang digunakan adalah dengan mengadakan kompetisi Spelling Bee yang akan dilaksanakan dalam tiga babak, yaitu Preliminary Round, Semi Final Round, dan Babak Final untuk semua siswa kelas 2 di MTSN 7 Bungus, Kota Padang yang berjumlah 280 siswa. Implementasi kegiatan pengabdian kepada masyarakat yang dilakukan dimulai dari tahap persiapan yang mencakup beberapa prosedur yaitu menyiapkan materi kosakata yang akan diperlombakan untuk ketiga tahapan lomba mulai dari tingkat kesulitan terendah hingga tersulit untuk dibabak finalnya. Pemilihan kosakata dan tingkat kesulitan telah disesuaikan dengan kemampuan siswa dan disetujui oleh guru dari sekolah. Prosedur kedua adalah mensurvei lokasi dan mengurus beberapa surat perizinan yang diperlukan, diantaranya adalah surat tugas dari perguruan tinggi dan surat izin melaksanakan PKM dari sekolah. Setelah pengurusan surat menyurat selesai, tim PKM melanjutkan untuk membuat proposal kegiatan PKM.

Setelah memaksimalkan persiapan, screening kemudian menjadi agenda selanjutnya. Ada beberapa tahap yang dilakukan yaitu menyiapkan materi lomba, susunan acara, panitia dan juri, menyiapkan peserta yang dilakukan oleh guru Bahasa Inggris anak, memastikan semua peralatan siap dibawa ke lokasi dan memastikan semua kebutuhan acara seperti transportasi dan spanduk.

Tindakan atau pelaksanaan dari rencana yang sudah disusun dalam sosialisasi dan edukasi yang diberikan kepada siswa-siswi Sekolah Dasar Negeri 13 Kuranji, Kota Padang, diantaranya perkenalan dengan menjelaskan aturan kompetisi. Peraturan umum dari kompetisi Spelling Bee yang akan diadakan adalah babak Pertama, Preliminary Round, diikuti oleh seluruh siswa. Di babak ini, Siswa harus dapat menjawab 3 soal. Siswa yang dapat menjawab minimal 2 soal dapat lanjut ke Babak berikutnya. Babak Kedua, adalah babak Semi Final. Sama seperti Babak sebelumnya, Siswa harus dapat menjawab 3 soal dengan tingkat yang lebih sulit. Siswa yang dapat menjawab minimal 2 soal dapat lanjut ke Babak berikutnya. Babak ketiga adalah babak Final. Pada babak ini, semua siswa yang lulus ke babak final akan diminta untuk mengeja kata sebanyak-banyaknya. Siswa yang dapat mengeja kata paling banyak akan menjadi pemenangnya. Terakhir, tim Dosen PKM UPI YPTK akan memberikan hadiah pagi juara 1, 2 dan 3 serta hadiah hiburan bagi semua peserta yang lulus ke babak final.

Implementasi kegiatan berikutnya adalah evaluasi. Evaluasi dilakukan untuk meninjau keberhasilan seluruh proses kegiatan PKM yang dilakukan. Untuk menilai keberhasilan program kegiatan ini adalah :

a. $80 \%$ peserta yang diundang hadir dalam sosialisasi dan edukasi. 
Jurdimas (Jurnal Pengabdian Kepada Masyarakat) Royal

Vol. 4 No. 2, Mei 2021, hlm. 157 - 164

ISSN 2614-7912 (Print)

DOI: https://doi.org/10.33330/jurdimas.v4i2.974

ISSN 2622-3813 (Online)

Available online at https://jurnal.stmikroyal.ac.id/index.php/jurdimas

b. Terlaksananya seluruh kegiatan pelatihan

c. $20 \%$ dari keseluruhan peserta kompetisi lolos ke babak final

d. Pernyataan kepuasan dan antusiasme belajar dari siswa-siswi MTSN 7 Bungus, Kota Padang peserta sosialisasi dan edukasi.

Implementasi kegiatan yang terakhir adalah penulisan laporan kegiatan. Laporan kegiatan disusun oleh Tim PKM Mandiri UPI YPTK Padang setelah kegiatan selesai dilaksanakan. Laporan kegiatan kemudian diserahkan kepada LPPM UPI YPTK Padang.

Untuk mengadakan PKM Spelling Bee di MTSN 7 Bungus, Kota Padang maka diperlukan jenis kepakaran bidang Pendidikan Bahasa Inggris dan bahasa Inggris dan Sistem Informasi untuk menjadi panitia dan juri yang kompeten untuk menilai kemampuan Bahasa Inggris siswa. Selain itu, kegiatan ini juga memerlukan keahlian dalam menfasilitasi kesuksesan acara yang menggunakan power point dan peralatan lainnya.

Kegiatan pengabdian kepada masyarakat memiliki target kegiatan yaitu siswa siswi Kelas 2 MTSN 7 Bungus, Padang. Kegiatan ini berbasis pengabdian kepada masyarakat berupa sosialisasi dan edukasi dalam kompetisi Spelling Bee yang dilaksanakan oleh TIM Dosen PKM UPI YPTK Padang. Kompetisi Spelling Bee dapat memberikan banyak manfaat bagi siswa yang ikut dalam kompetisi ini. Harapan utama kegiatan pengabdian kepada masyarakat Spelling Bee ini adalah memberikan stimulasi kepada siswa dalam mengenal huruf dan kata hingga dapat meningkatkan kemampuan Speaking dan writing siswa dengan cara yang menyenangkan.
Dimana dengan adanya kegiatan PKM Spelling Bee ini diharapkan:

1. Mampu mengeja dan mengenali kosakata Bahasa Inggris dengan benar.

2. Menambah jumlah pengetahuan kosa kata siswa dalam Bahasa Inggris

3. Memberikan semangat dan motivasi bagi siswa dalam belajar Bahasa Inggris

4. Memiliki rasa percaya diri dalam berbahasa Inggris

5. Meningkatkan kemampuan berbicara dan menulis dalam Bahasa Inggris.

\section{PEMBAHASAN}

MTsN 7 Bungus, Padang jarang sekali mendapatkan kunjungan dari universitas untuk mengadakan PKM, karenanya pihak sekolah sangat bersemangat untuk mengadakan kompetisi mengeja atau Spelling Bee ini bersama tim PKM dari UPI YPTK padang untuk meningkatkan kemampuan speaking dan writing siswa-siswinya khusunya terhadap kosakata kosakata sederhana.

Pada saat sebelum mengadakan kegiatan PKM ini, siswa-siswa juga telah dibekali dengan pengetahuan mengeja dalam bahasa Inggris. Namun, penerapannya sangatlah minim. Umumnya hanya berupa latihan dari guru kelasanya saja. Dengan diadakannya PKM ini, siswasiswa kelas 8 MTsN 7 Bungus mengetahui bahwa berlatih mengeja huruf tidak saja dapat meningkatkan kualitas speaking dan writing ya, namun juga menjadi kegiatan yang menyenangkan.

Kegiatan PKM yang dilaksanakan ini merupakan gabungan antara pemberian materi, pelajaran, kompetisi dan permainan.Siswa-siswi kelas 8 berlomba 
Jurdimas (Jurnal Pengabdian Kepada Masyarakat) Royal

Vol. 4 No. 2, Mei 2021, hlm. 157 - 164

ISSN 2614-7912 (Print)

DOI: https://doi.org/10.33330/jurdimas.v4i2.974

ISSN 2622-3813 (Online)

Available online at https://jurnal.stmikroyal.ac.id/index.php/jurdimas

untuk dapat mengeja satu persatu kosa kata yang didengarnya. Kegiatan ini kemudian dapat berhasil menghidupkan semangat siswa dalam belajar, meningkatkan rasa percaya diri dan meningkatkan kemampuan menulis dan berbicara dalam bahasa Inggris.Bagi siswa tingkat Sekolah Menegah Pertama, Bahasa Inggris masih dianggap sebagai bahasa yang sulit untuk dikuasi dan dipelajari.

Setelah melakukan berbagai persiapan, tim PKM UPI YPTK kemudian dapat melaksanakan kompetisi mengeja dalam bahasa Inggris kepada delapan kelas anak kelas 8, yang tiap-tiap kelasnya berjumlah 30 sampai 35 orang. Dari masing-masing kelas, setelah diadakan pelatihan dan penyeleksian awal terpilih 510 siswa untuk mengikuti kompetisi mengeja ketahap selanjutnya. Kemudian, wakil dari kelas masing-masing mengikuti kompetisi Spelling Bee sehingga terpilih juara 1,2 dan 3 serta 15 orang finalis yang mendapat hadiah dan apresiasi dari tim PKM dan Pihak sekolah.

Tercapainya hasil yang memuaskan dalam PKM ini disebabkan oleh beberapa faktor. Faktor pertama adalah pemberi Materi. Pemberi materi memegang peranan penting dalam PKM ini. Masing-masing anggota tim PKM yang juga merupakan dosen bahasa Inggris di Universitas Putra Indonesia bertugas juga sebagai pemberi materi. Materi yang diberikan adalah berupa cara mengeja dan mengenal kosakata. Faktor kedua adalah penerima Materi. Dalam kegiatan ini, penerima materi adalah siswa siswi kelas 8 MTsN Bungus, Padang. Mereka dipilih berdasarkan pertimbangan bahwa anakanak kelas 8 sudah cukup pengetahuan dan latihan dalam belajar bahasa Inggris di tingkat sekolah menengah pertama. Faktor berikutnya adalah metode Pelaksanaan. Metode Pelaksanaan PKM ini telah dirancang dengan menggunakan metode yang menyenangkan, ringan namun kompetitif. Oleh karena itu, meskipun anak-anak tidak terpaksa untuk mengikuti kegiatan ini, namun hadiah-hadiah dan apresiasi yang diberikan membuat siswasiswi tersebut bersemangat untuk mengikuti kegiatan ini. Faktor terakhir adalah materi yang diberikan. Dalam kegiatan ini, materi yang diberikan diantaranya adalah kosakata-kosakata sederhana yang juga terdapat dalam buku pelajaran bahasa Inggris di sekolah tersebut. Kosakata tersebut yaitu kosakata dengan 2 suku kata, 3 suku kata, 4 suku kata dan compound Noun (kata benda majemuk).

Dengan dilaksanakannya kegiatan PKM ini, telah muncul beberapa pengaruh yang signifikan baik bagi peserta PKM yaitu siswa-siswa MTsN 7 Bungus kelas 8, maupun kepada bagi Tim Guru di sekolah tersebut. Melihat tingginya minat dan semangatbanak-anak dalam mengikuti kegiatan kompetisi Spelling Bee ini, pihak guru menantikan agar panitia tim PKM dapat melakukan kegiatan-kegiatan yang sama pada periode-periode yang akan datang. Selain itu, anak-anak yang terlah berhasil menjuarai kompetisi ini dapat diikutikan pada kompetisi dengan tingkat yang lebih tinggi lagi.

Harapan utama kegiatan pengabdian kepada masyarakat Spelling Bee ini adalah memberikan stimulasi kepada siswa dalam mengenal huruf dan kata hingga dapat meningkatkan kemampuan Speaking dan writing siswa dengan cara yang menyenangkan. 


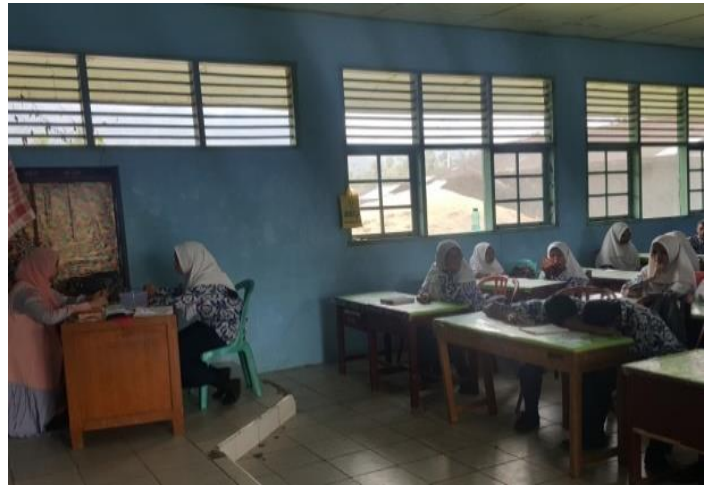

Gambar 1 Seleksi awal babak Preliminary round kompetisi Spelling Bee

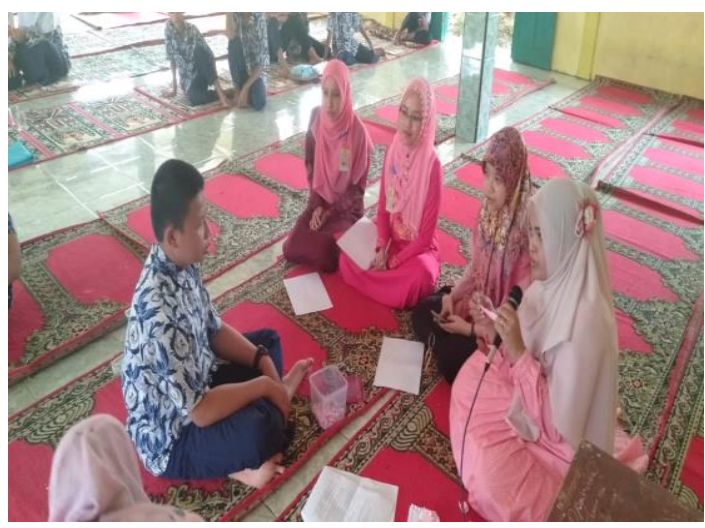

Gambar 2 Babak Final Spelling Bee

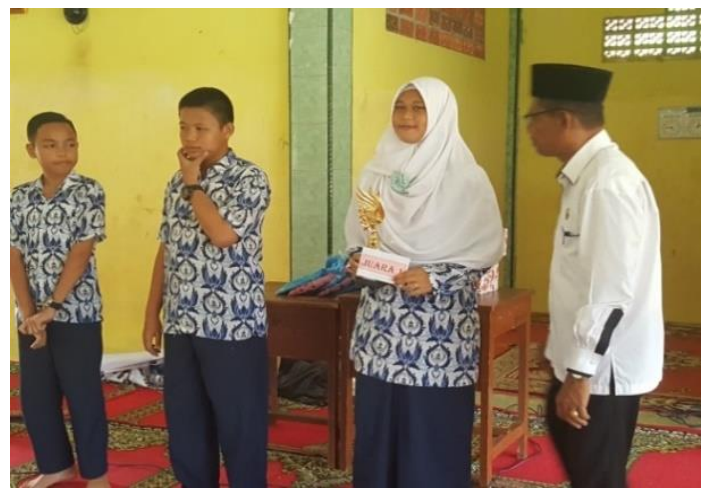

Gambar 3 Pembagian hadiah oleh kepala sekolah

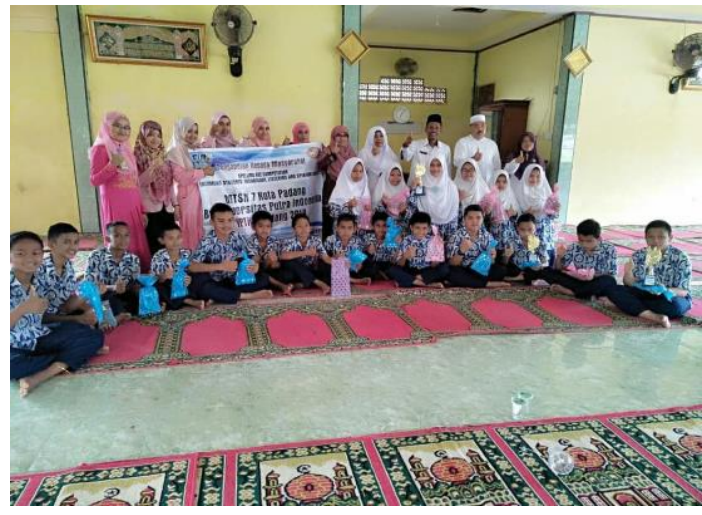

Gambar 4 Foto bersama Guru, kepala sekolah dan Juara kompetisi

\section{SIMPULAN}

Setelah melakukan Kegiatan PKM Spelling Bee di MTsN 7 Bungus Padang, dapat disimpulkan bahwa kegiatan ini telah berhasil dilaksanakan dengan baik dan lancar sesuai dengan target dan luaran yang telah direncanakan sebelumnya. Berdasarkan hasil obervasi di lapangan, siswa-siswa kelas 8 yang mengikuti kegiatan PKM ini kembali menguasai cara mengeja dalam bahasa Inggris dan mengenal beberapa kosakata sederhana. Dengan demikian, siswa-siswi ini akan dapat meningkatkan kemapuan speaking dan writing khususnya pada kosakata sederhana yang telah diperkenalkan.

Oleh karena itu, diharapkan memang jika kegiatan seperti ini dapat dilakukan secara berkala dan mendapatkan dukungan dari berbagai pihak. Selain kegiatan Spelling Bee ini, kemampuan speaking dan writing siswa juga dapat ditingkatlan dalam banyak kegiatan lagi seperti debate contest, speech contest, writing essay, dll. Tim PKM juga berharap dapat menghadirkan kegiatan dimana siswa-siswi dapat mempraktekkan bahasa 
Inggrisnya dengan native speaker seperti mengadakan Family gahering di ruangruang terbuka.

Rencana tindak lanjut pasca kegiatan Spelling Bee ini adalah adanya upaya pendampingan secara berkala pada kemampuan mengeja kosakata, dan memantau kemajuan kemampuan speaking dan writing siswa dalam menulis kosakata sederhana. Selain itu, tim PKM juga mempertimbangkan permintaan pihak sekolah untuk kembali mengadakan kompetisi-kompetisi berbahasa Inggris pada periode waktu berikutnya.

\section{DAFTAR PUSTAKA}

Aprillia, A. (2018). The Use of Spelling Bee Games to Increase Students' Vocabulary Mastery at Muhammadiyah Ahmad Dahlan Junior High School of Metro. Institut Negeri Islamic Studies of Metro, Metro.

Kamhi, A. G., \& Hilton, L. . (2000). Explaining Individual Differences in Spelling Ability. Topics on Language Disorders, 20(3).

Phoenix, J., \& Scott-Dunne, D. (1994).
Spelling for Parents. Pembroke Publishing Ltd.

Rollings, A. (2004). The Spelling Patterns of English. Munich: Meunchen LINCOM Europe.

Strickland, D. (2011). Teaching Phonics Today: Word Study Strategies through the Grades. International Reading Association (2nd ed.). Newark: DE: International Reading Association.

Syakira, R. (2018). Pengaruh Penggunaan Permainan Spelling Bee untuk Meningkatkan Pemahaman Membaca Siswa di SMP Negeri 40 Pekanbaru. Universitas Sultan Syarif Kasim, Pekanbaru.

Waller, S. (2002). The Spelling Dillema. English Teaching Professional, 24(1), 13-15.

Yule, G. (2006). The Study of Language. India: Cambridge University Press.

Yusuf, Y. Q., Mustafa, F., \& Muzdhalifah, A. (2017). The Use of Spelling Bee Game in Teaching Vocabulary to Junior High School Students. In Proceeding of the First National Conference on Teacher's Professional Development (p. ). Banda Aceh. 